\title{
Yield Attributes and Yield of Pigeonpea [Cajanus cajan (L.) Millsp.] As Influenced by Growth Retardants and Sowing Dates
}

\author{
Amandeep Kaur, Harmeet Singh" and J.S. Kang \\ Department of Agronomy, Punjab Agricultural University, Ludhiana, Punjab-141004, India \\ *Corresponding author
}

A B S T R A C T

\begin{tabular}{|l|}
\hline Ke y w or d s \\
Pigeonpea, Sowing \\
time, Growth \\
Retardants, Maleic \\
hydrazide, TIBA, \\
Productivity. \\
\hline Article Info \\
\hline $\begin{array}{l}\text { Accepted: } \\
\text { 17 July } 2017 \\
\text { Available Online: } \\
\text { 10 September } 2017\end{array}$ \\
\hline
\end{tabular}

A field experiment was conducted at Punjab Agricultural University, Ludhiana during kharif 2016 to study the effect of eight growth retardant treatments viz., control, water spray, MH @ 200, 250 and 300 ppm and TIBA @ 25, 50 and 75 ppm and two sowing dates (May 15 and May 30) on yield attributes and yield of pigeonpea. May 15 sown crop produced significantly higher number of branches, pods plant ${ }^{-1}$ and grain yield than May

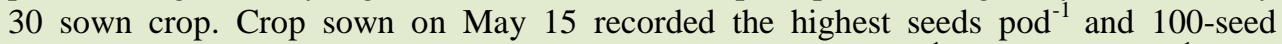
weight. Various yield attributes viz., secondary branches plant ${ }^{-1}$ and pods plant ${ }^{-1}$ were statistically higher with application of TIBA @ 75 ppm than all other growth retardant treatments and control but was statistically at par with TIBA applied @ 50 ppm. As a result, highest seed yield of pigeonpea $\left(14.4 \mathrm{q} \mathrm{ha}^{-1}\right)$ was recorded with application of TIBA @ 75 ppm although at par with foliar application of TIBA @ 50 ppm but was 22.9 per cent higher than control. Among the growth retardants, TIBA @ 75 ppm produced highest number of seeds pod $^{-1}$ and 100 -seed weight.

\section{Introduction}

Pigeonpea [Cajanus cajan (L.) Millsp.] also known as arhar or tur or redgram, is the second most significant pulse crop of India after Bengalgram. In Punjab pigeonpea was grown on an area of 2.6 thousand hectares and the total production was 2.63 thousand tonnes with average yield of 10.13 quintals hectare ${ }^{-1}$ (Anonymous 2017). Being a legume crop, it acts as a soil ameliorant and is known to provide different benefits to the soil in which it is grown. The seeds, pods and leaves are used by human and livestock being rich in nutrition. Pigeonpea crop generally enhances soil fertility through leaf litter and biological nitrogen fixation (Udaya et al., 2015). Plant growth retardants are synthetic substances, which are mostly used to reduce the intermodal length of plants in a desired pattern without changing the development practice or being phytotoxic. Plant growth retardants are known to improve source-sink relationship, improve photosynthetic ability and better fruit retention by curtailing the excessive vegetative growth (Kaur et al., 2013). So to achieve optimum vegetative growth and to effect better translocation of photosyntates into the developing pods, use of growth retardants appears to be an effective approach. Maleic hydrazide (1, 2 dihydro-3, 6-pyridzinedione), cause inhibition of seedling growth by inhibiting mitotic cell division in plants. Maleic hydrazide $(\mathrm{MH})$ 
acts by curtailing of excessive vegetative growth by inhibiting the biosynthesis of nucleic acid (Ranjan et al., 2004) and results in dwarfed plants with short internodes and dark green colour leaves without affecting the nodel length. TIBA (2, 3, 5-triiodo benzoic acid) is used in agriculture crops for curtailing the extra vegetative growth and to check the lodging, lowering the abscission of flowers and young unripe pods and for alteration of crop architecture to enhance the productivity of crops (Adam and Jahan 2014). Sowing dates has a profound impact on the crop performance as it determines the kind of environmental conditions to which difficult phenological stages of the crop exposed. Delay in sowing time shortens the growing period, hastens maturity and ultimately reduces the yield (Singh and Dixit 1992). Early sowing may encourage the vegetative growth which may make the crop prone to different insect pests and diseases. On the other hand, delayed sowing may shrink the vegetative phase, thereby resulting in poor dry matter accumulation leading to poor partioning to reproductive parts and ultimately poor realization of the potential yield.

\section{Materials and Methods}

The experiment was conducted at Punjab Agricultural University, Ludhiana during kharif seasons of the year 2016. Ludhiana, which represents the trans-Indo-Gangetic alluvial plains, is situated at the ${ }^{\circ} 54^{\prime} \mathrm{N}$ latitude, $75^{\circ} 48^{\prime} \mathrm{E}$ longitude and at an altitude of $247 \mathrm{~m}$ above the mean sea level. The experiment was conducted in Randomized Complete Block Design comprising sixteen treatment combinations including two sowing dates (May 15 and May 30) and eight plant growth retardant treatments (control, water spray, MH@200, 250 \& 300 ppm, TIBA @ 25, 50 $\& 75 \mathrm{ppm})$ at 60 and 80 days after sowing was conducted in Randomized Complete
Block Design with three replications. Seeds of cultivar PAU 881 were treated with recommended fungicide and inoculation with rhizobium culture was done prior to sowing. Crop was sown at a spacing of $50 \mathrm{~cm} \times 25 \mathrm{~cm}$ on a well prepared seed bed. Recommended fertilizers were applied at the time of sowing.

Data on various parameters was recorded periodically. Observations on five random plants from each plot were recorded for primary and secondary branches plant ${ }^{-1}$, pods plant ${ }^{-1}$ and seed pod $^{-1}$. From the total produce of the plot 100 seeds were taken randomly and counted and weighed for 100-seed weight.

\section{Results and Discussion}

\section{Effect of sowing dates}

Primary branches per plant were significantly more in the early sown crop (May 15) than the late sown crop. Earlier sown crop (May 15) produced 14.9 per cent higher number of secondary branches (29.5) as compared to late sown crop (25.1). This may be attributed due to favorable environmental conditions for early sown crop particularly during the vegetative growth phase. Ram et al., (2011) also reported higher number of primary and secondary branches from early sown pigeonpea. The number of pods plant $^{-1}$ is an important character which directly influences seed yield of the crop. May 15 sown crop produced significantly higher number of pods than May 30 sown crop (Table 1).

May 15 sown crop gave 6.6 per cent higher pods plant $^{-1}$ than May 30 sown crop. The increase in number of pods was attributed due to increase in number of branches plant ${ }^{-1}$ and better balance between the vegetative and reproductive phases. These results are in accordance with the earlier findings of Rani and Reddy (2010) and Singh et al., (2016). 
Seed pod $^{-1}$ and 100 -seed weight were highest in May 15 sowing; however, the differences among the sowing dates were non-significant for these yield parameters. Stover yield gives an estimate of the vegetative growth of the crop. It also helps in estimating the harvest index of crop. Indeterminate crops such as pigeonpea are characterized with high stover production which tends to lower their harvest index. The crop sown on May 15 produced higher stover yield (41.1 $\left.\mathrm{q} \mathrm{ha}^{-1}\right)$ than May 30 (39.9 $\mathrm{q} \mathrm{ha}^{-1}$ ) sown crop. The higher stover yield of early sowing was attributed to excessive vegetative growth and dry matter accumulation in vegetative parts as compared to reproductive parts. May 15 sowing gave significantly higher seed yield than May 30 sown crop. May 15 sown crop showed an increase of 11.3 per cent increase than May 30 sown crop. The higher seed yield from May 15 was cumulative favorable effect of various growth and yield attributes. As early sowing get favorable environmental condition for proper growth and development which resulted in higher leaf area development and high biomass accumulation which ultimately lead to significant improvement in seed yield. The crop sown on May 15 produced more number of primary and secondary branches which ultimately resulted in production of more number of pods plant ${ }^{-1}$ that too contributed towards higher seed yield. The higher seed yield may be attributed to high Leaf Area Index as well as higher PAR interception and absorption, leading to higher Dry Matter Accumulation before the attainment of reproductive stage by pigeonpea crop (Patel et al., 2000). Harvest index is a measure of physiological productivity potential of crop cultivars. Harvest index is the ability of a plant to convert the dry matter into economic yield. Harvest index was significantly influenced by sowing dates. May 15 sown crop produced higher harvest index (0.24) than May 30 sown (0.23) crop. Similar, results was reported by Islam et al., (2008).

Table.1 Effect of sowing dates and growth retardants on yield and yield attributes of pigeonpea

\begin{tabular}{|c|c|c|c|c|c|c|c|c|}
\hline Treatment & $\begin{array}{c}\text { Number of } \\
\text { primary } \\
\text { branches } \\
\text { plant }^{-1}\end{array}$ & $\begin{array}{c}\text { Number of } \\
\text { secondary } \\
\text { branches } \\
\text { plant }^{-1}\end{array}$ & $\begin{array}{c}\text { Pods } \\
\text { plant }^{-1}\end{array}$ & $\begin{array}{c}\text { Seeds } \\
\text { pod }^{-1}\end{array}$ & $\begin{array}{c}\text { 100- } \\
\text { seed } \\
\text { weight } \\
\text { (g) }\end{array}$ & $\begin{array}{l}\text { Seed } \\
\text { yield } \\
\left(\mathbf{q} \mathbf{h a}^{-1}\right)\end{array}$ & $\begin{array}{c}\text { Stover } \\
\text { yield } \\
\left(\mathbf{q} \mathbf{h a}^{-1)}\right.\end{array}$ & $\begin{array}{l}\text { Harvest } \\
\text { Index }\end{array}$ \\
\hline \multicolumn{9}{|l|}{ Sowing dates } \\
\hline May 15 & 20.2 & 29.5 & 139.0 & 3.22 & 6.86 & 13.3 & 41.1 & 0.24 \\
\hline May 30 & 14.3 & 25.1 & 129.8 & 3.00 & 6.66 & 11.8 & 39.9 & 0.23 \\
\hline$C D(p=0.05)$ & 0.95 & 1.82 & 6.9 & NS & NS & 0.63 & NS & 0.01 \\
\hline \multicolumn{9}{|l|}{ Growth retardants } \\
\hline Control & 15.7 & 23.7 & 116.0 & 2.83 & 6.45 & 11.1 & 38.0 & 0.22 \\
\hline Water spray (60 \& 80DAS) & 16.0 & 24.2 & 120.3 & 2.92 & 6.52 & 11.2 & 38.9 & 0.22 \\
\hline MH @ 200 ppm (60 \& 80 DAS) & 17.7 & 26.9 & 134.6 & 3.12 & 6.82 & 12.6 & 42.0 & 0.23 \\
\hline MH @ 250 ppm (60 \& 80 DAS) & 17.2 & 26.0 & 132.5 & 3.1 & 6.78 & 12.4 & 40.1 & 0.23 \\
\hline MH @ 300 ppm (60 \& 80 DAS $)$ & 17.0 & 27.4 & 129.3 & 3.02 & 6.57 & 12.3 & 39.4 & 0.24 \\
\hline $\begin{array}{l}\text { TIBA @ } 25 \text { ppm }(60 \& 80 \\
\text { DAS })\end{array}$ & 17.9 & 27.1 & 135.1 & 3.17 & 6.83 & 12.5 & 43.3 & 0.23 \\
\hline $\begin{array}{l}\text { TIBA @ } 50 \text { ppm }(60 \& 80 \\
\text { DAS) }\end{array}$ & 18.1 & 31.3 & 153.1 & 3.29 & 7.04 & 14.0 & 40.6 & 0.25 \\
\hline $\begin{array}{l}\text { TIBA @ } 75 \text { ppm }(60 \& 80 \\
\text { DAS) }\end{array}$ & 17.4 & 32.3 & 154.6 & 3.45 & 7.06 & 14.4 & 41.2 & 0.25 \\
\hline $\mathrm{CD}(\mathrm{p}=0.05)$ & NS & 3.7 & 13.7 & NS & NS & 1.25 & NS & 0.02 \\
\hline Interaction & NS & NS & NS & NS & NS & NS & NS & NS \\
\hline
\end{tabular}




\section{Effect of growth retardants}

Higher number of primary branches per plant was observed with TIBA applied @ 75 ppm. The higher number of secondary branches plant $^{-1}$ were recorded with the application of TIBA @ 75 ppm which was statistically at par with TIBA applied @ 50 ppm but were significantly better than other growth retardant treatments and control. TIBA@75 ppm produced 26.6 per cent higher secondary branches over control.

The increase in number of branches with application of growth retardants was due to inhibition of apical dominance and breaking of lateral bud dormancy that resulted in more number of secondary branches.

Different growth retardant treatments were significantly better than control in producing more number of pods. TIBA @ 75ppm produced maximum number of pods (154.6) which was statistically at par with TIBA applied @ 50 ppm (153.1), but significantly better than other treatments viz., TIBA applied @25 ppm (135.1), MH @200 ppm (134.2), MH @ 250 ppm (132.2), MH @ 300 ppm (129.3), water spray (126.0) and control (118.6). TIBA@25 ppm and MH @200 ppm gave significantly higher number of pods per plant as compared to water spray and control. TIBA @ 75 ppm and TIBA @ 50 ppm produced 23.3 and 22.5 per cent higher number of pods per plant respectively than control.

Higher rate of TIBA application (50 ppm) application significantly increased the pods plant $^{-1}$ (Tripathi et al., 2009). Seeds pod and 100-seed yield was highest in TIBA@75 ppm and minimum in control however, these two yield contributing parameters were nonsignificantly affected by application of growth retardants. Stover yield was maximum in TIBA@ 25 ppm (43.3 q ha $\left.{ }^{-1}\right)$ followed by other growth retardants treatments viz., TIBA @ 75 ppm (41.2 q ha $\left.{ }^{-1}\right)$, TIBA @ 50 ppm (40.6 q ha $\left.{ }^{-1}\right)$, MH @ 200 (42.0 q ha $\left.{ }^{-1}\right)$, MH @ 250 ppm (41.0 q ha $\left.{ }^{-1}\right)$ and $\mathrm{MH} @ 300$ ppm (39.4 q ha ${ }^{-1}$ ), water spray (38.9 q ha ${ }^{-1}$ ) and control (38.0 q ha $\left.{ }^{-1}\right)$. TIBA @ 75 ppm produced maximum seed yield (14.4) which was statistically at par with TIBA @ 50 ppm (14.0) and these two treatments were significantly better than other growth retardants and control (11.1). TIBA applied @ 75 and $50 \mathrm{ppm}$ showed an increase of 22.9 and 20.7 per cent in seed yield, respectively as compared to control. Among the other treatments, MH applied @ 200 ppm gave higher seed yield than the higher concentrations of MH @ 250 and 300 ppm, water spray and control. MH @ 200 ppm produced 11.9 per cent higher seed yield than control.

Application of lower dose of TIBA @ 25 ppm produced higher seed yield (12.5) than $\mathrm{MH}$, water spray and control. TIBA @ 25 ppm showed an increase of 11.2 per cent over control. The increase in seed yield may be accrued to diversion of photosynthates from vegetative parts to the reproductive parts i.e. pods which ultimately leads to increase in seed yield.

The improvement in yield and yield attributing characters of pigeonpea by the application of growth retardants might be owing to its positive effect on growth which in turn resulted in the development of higher yield attributing characters and ultimately increased seed yield (Deotale et al., 1995, Arora et al., 1998, Upadhaya 2002 and Kiran et al., 2005).

The highest value of harvest index (0.25) was recorded with application of TIBA applied @ 75 ppm which was at par with TIBA@50 ppm (0.25) and MH @ 300 ppm (0.24) and significantly better than all other treatments. 
The maximum harvest index may be accounted as a function of growth retardants which improved the source-sink relationship by enhancing the diversion of photosynthates towards vegetative parts to reproductive parts. TIBA application significantly increased the seed yield and harvest of pigeonea (Tripathi et al., 2009).

\section{References}

Adam Golam, A.M.M., and Jahan N 2014. Growth and yield of bari mung- 5 (Vigna radiata) following TIBA application. $J$ Biol Sci 23: 179-85.

Anonymous, 2017. Package of practices for Crops of Punjab-Kharif 2017. Pp 62. Punjab Agricultural University Ludhiana.

Arora, N., Kaur Balwinder, Singh Parmial and Parmar Usha 1998. Effect of IAA and cycoel on yield contributing parameters of chickpea (Cicer arietinum L.) Ann Agric Res 19: 279-81.

Deotale, R.D., Katekhaye D S, Sote N V, Raut J S and Golliwar V J 1995. Effect of TIBA and B-nine on morpho-logical character of soybean. J soils Crops 5: 172-76.

Islam, S., Nanda M K and Mukherjee A K 2008. Effect of date of sowing and spacing on growth and yield of Rabi Pigeonpea (Cajanus cajan (L.) Millsp.). J Crop Weed 4:7-9.

Kaur, R., Rajni, Deol J S, Das A 2013. Physiology of abscission and crop regulation in cotton-a review. Ann Agric Res 34: 287-93.

Krian Kumar, K.A., Patil B C and Chetti M B 2005. Effect of plant bioregulators on physiological components by yield in hybrid cotton. Indian Journal of Plant Physiology 10: 187-90.

Patel, N.R., Mehta A.N., and Shekh AM 2000.
Radiation Absorp-tion, Growth and Yield of Pigeon pea Cultivars as Influenced by Sowing Dates. Exp Agric 36: 291-301.

Ram, H., Singh G, Sekhon H S and Khanna V 2011. Effect of sowing time on the performance of pigeonpea genotypes. $J$ Food Leg 24:207-10.

Rani, B.P., and Reddy D R 2010. Performance of Pigeonpea in Sole and Intercropping System in Vertisols of Krishna-Godavari Zone in Andhra Pradesh. Indian J Agric Res 44(3): 225-28.

Ranjan, R., Purohit S.S., and Prasad V 2004. Plant Hormone: Action and Application. Pp 1-242. Agrobios (India), Jodhpur.

Singh, G., Kaur H, Aggarwal N, Ram H, Gill K $\mathrm{K}$ and Khanna V 2016. Symbiotic characters, thermal requirement, growth, yield and economics of pigeonpea (Cajanus cajan) genotypes sown at different dates under Punjab conditions. $J$ Appl Natural Sci 8: 381-85.

Singh, V.K., and Dixit R S 1992. Effect of moisture regime and sowing date on chickpea. Indian J Agron 37: 739-43.

Tripathi, D.K., Kumar A and Awasthi U D 2009. Response of bio-regulators on flower drop, growth and yield of Pigeonpea (Cajanus cajan). Curr $A d v$ Agric Sci 1: 33-34.

Udhaya, N.D., Vimalendren L, Letha K R, Sangamithra S and Kalaiyarasan V 2015. A Review on biological advantage of Pigeonpea intercropping influenced by different cropping geometries. Int J Agric Sci Res 5: 103-12.

Upadhyaya, R.G., 2002. Response of bioregulators on flower drop, fruit setting biochemical constituents and yield of chickpea (Cicer arietinum L.) under mild hill condition of H.P. Legume Research 25: 211-14.

\section{How to cite this article:}

Amandeep Kaur, Harmeet Singh and Kang, J.S. 2017. Yield Attributes and Yield of Pigeonpea [Cajanus cajan (L.) Millsp.] As Influenced by Growth Retardants and Sowing Dates. Int.J.Curr.Microbiol.App.Sci. 6(9): 1201-1205. doi: https://doi.org/10.20546/ijcmas.2017.609.145 